University of California, Hastings College of the Law UC Hastings Scholarship Repository

Faculty Scholarship

1988

\title{
Reforming the Mining Law: Problems And Prospects
}

John D. Leshy

UC Hastings College of the Law, leshyj@uchastings.edu

Follow this and additional works at: http://repository.uchastings.edu/faculty_scholarship

Part of the Natural Resources Law Commons, and the Water Law Commons

\section{Recommended Citation}

John D. Leshy, Reforming the Mining Law: Problems And Prospects, 9 Pub. Land L. Rev. 1 (1988).

Available at: http://repository.uchastings.edu/faculty_scholarship/391

This Article is brought to you for free and open access by UC Hastings Scholarship Repository. It has been accepted for inclusion in Faculty Scholarship by an authorized administrator of UC Hastings Scholarship Repository. For more information, please contact marcusc@uchastings.edu. 


\section{Faculty Publications \\ UC Hastings College of the Law Library}

Author: John D. Leshy

Source: $\quad$ Public Land Law Review

Citation: 9 Pub. Land L. Rev. 1 (1988).

Title: $\quad$ Reforming the Mining Law: Problems And Prospects

Originally published in PUBLIC LAND LAW REVIEW. This article is reprinted with permission from PUBLIC LAND LAW REVIEW and University of Montana School of Law. 


\title{
ARTICLES
}

\section{REFORMING THE MINING LAW: PROBLEMS AND PROSPECTS}

\author{
John D. Leshy*
}

\section{INTRODUCTION}

Legislative efforts to reform the venerable Mining Law of $1872^{1}$ appear to be emerging from the coma into which they slipped more than ten years ago. For aficionados of public lands policy, that is genuine news. The Mining Law, the undisputed surviving king of nineteenth century congressional underpinnings of the westward expansion, has stubbornly resisted fundamental reform throughout its long life. Most of its counterparts like the Homestead $\mathrm{Act}^{2}$ have long since faded into oblivion, even though many were not formally repealed until relatively recently. ${ }^{3}$

The Mining Law has survived despite strenuous efforts, led in modern times primarily by environmental protection advocates, to replace it with a framework for hardrock mineral development more consonant with contemporary values and imperatives. In mining parlance, so far the environmentalists have broken their picks on the Mining Law, in sharp contrast to their remarkable string of legislative successes in the last couple of decades.

The reasons underlying the lack of legislative movement are varied. Indeed, it is not completely accurate to say that there has been no change in the law because it has, quietly but steadily, been "reformed" by a combination of legislative, administrative, and judicial action. I reviewed those actions, and explored the reasons behind the absence of more fundamental reform, in a book published about eighteen months ago. ${ }^{4}$

In this article I will focus on the events that have occurred since my book was written-in effect, I aim to furnish an epilogue to it. I will

\footnotetext{
* Professor of Law, Arizona State University. The author appreciates the helpful ideas offered by Bob Uram, Mike Harvey, and Jim Zoia. Mr. Leshy delivered a version of this paper at the Tenth Annual Public Land Law Conference, University of Montana School of Law, Missoula, April 8, 1988.

1. 30 U.S.C. $\$ \$ 21-54$ (1982).

2. 12 Stat. 392 (1862).

3. See Federal Land Policy and Management Act of 1976, $\$$ 702-06, 90 Stat. 2787-94 (1976).

4. J. Leshy, The Mining LAw: A Study in Perpetual Motion 186-370 (1987) [hereinafter cited as The Mining LAw].
} 
reexamine the politics of Mining Law reform in light of those intervening events, and update the suggestions I offered there on possible grounds for legislative compromise. I will also describe what.I think would be the most likely consequences of a continuing failure to achieve legislative reform. I suggested some of these in my book, ${ }^{5}$ but subsequent developments cast new light on the matter.

\section{Reforming the Mining Law: The First Century}

I do not want to overstate the significance of recent events. No wave of reformist sentiment is about to envelop the Mining Law. Instead, there are some ripples in a pond that has been calm for over a decade. History provides scant support for the notion that such ripples can turn into tidal waves. One chapter in my book recounts the consistent failure of reform efforts. ${ }^{6}$ I propose here to synthesize enough of that discussion to lay the groundwork for discussing the current reform landscape.

Modern attempts to reform the Mining Law have accustomed public lands observers to view the struggle as a bare-knuckled contest between environmentalists and the hardrock mining industry. But that was not always the case and, indeed, it is still not completely the case. Instead, "considered solely from the perspective of promoting mineral development, the Mining Law was widely regarded as outdated and inadequate almost from the moment it was enacted."7

The first of a long line of blue-ribbon commissions examining the Mining Law, the 1880 Public Land Commission, recommended it be thoroughly rewritten. In one of the worst predictions in public land management history, one of the Commissioners confidently stated that the Mining Law "will, in the near future, have to be materially changed. . .for the better security of. . .title and respect for the rights of property."

Yet the statute has not been formally changed to correct the basic defects noted by this and every other body that has studied the law. These defects, rooted primarily in the statute's crude attempts to ratify the practices adopted by the fledgling hardrock industry in the precious metal "rushes" between 1848 and 1866, have become more pronounced with the vast changes that have taken place in the industry in the last century. The principal effect of these shortcomings on the industry is a chronic, neartotal lack of security of tenure for mining claims. ${ }^{9}$

\footnotetext{
5. Id. at $158-63,220-28,347-70$.

6. Id. at $287-312$.

7. Id. at $288-89$ (emphasis added).

8. T. Donaldson, The Public Domain: Its History with Statistics 541 (1884) (emphasis

9. The Mining LaW, supra note 4, at 89-181.
} added). 
Given these problems, it is astonishing that the Law has escaped fundamental change. If it provides such scanty security to legitimate mineral developers-such a morass of confusing and arbitrary requirements that bedevil mining claimants-why has Congress not been persuaded to act? Until about the middle of the twentieth century, concern about environmental protection was not really part of the debate. ${ }^{10}$ If the miners had the political field largely to themselves, why could they not muster enough support to correct these defects?

The answer is that the industry itself has never been able to forge agreement among its own members on the substance of needed change. Early on, a split emerged between the smaller prospectors or explorationists and the majors - the developers of large mines. The wide gulf between these two camps was nowhere better illustrated than in hearings conducted by a House Committee on a reform proposal made by the federal Bureau of Mines and the Mining and Metallurgical Society of America in 1922.11 The majors wanted better security of title, more protection against nuisance locators (especially during the exploration phase), and elimination of unnecessary red tape. The prospectors perceived these proposals as thinly veiled attempts to deprive them of access to federal lands. The majors regarded the prospectors as ignorant, misguided, and, in any event, no longer useful. The prospectors, in turn, regarded the majors as monopolistic robber barons, undemocratic and haughty. In the end, the prospectors won; the reform bill never emerged from committee.

Ironically, about the same time this struggle was taking place, a related battle was being waged in Congress over whether to remove most fuel and fertilizer minerals (principally oil, gas, oil shale, potash, sulfur, and phosphate) from the Mining Law. This effort was in response to the Law's gross inadequacy to deal with wide-area, expensive exploration of deposits of oil and gas concealed deep beneath the earth's surface. The Mining Law came perilously close to collapse in the race to locate and develop these deposits. Exploration was legally risky and litigation was endemic. Aided by executive orders withdrawing from the Mining Law much of the federal lands thought valuable for these minerals, reform advocates eventually prevailed in the Mineral Leasing Act of $1920{ }^{12}$

There are some interesting parallels between those reform efforts and the modern scene. Specifically, the Mining Law today poses the same kinds of problems for hardrock miners that it did for the oil and gas industry prior

10. Indeed, one of the leading defenders of the Mining Law in the early decades of this century was a long-time Sierra Club officer and activist, as well as an eminent mining lawyer and scholar, William Colby. Id. at 21.

11. Id. at $289-94$.

12. 30 U.S.C. $\$ \S 181-287$ (1982). See The Mining LAw, supra note 4, at 31-32, 102-04. 
to enactment of the Mineral Leasing Act. There is little security in the exploration phase; top-filing of claims and ensuing litigation is common. ${ }^{13}$ The limit on the size of individual claims (generally, 20 acres) is at best a nuisance and at worst an expensive headache, because aggregation of sufficient numbers of claims to support the pursuit of deposits can be difficult in practice, and maintaining large numbers of claims multiplies red tape. ${ }^{14}$ The statute's distinction between lode and placer claims and its other peculiarities can compound these problems. ${ }^{15}$

Moreover, the split in industry ranks exemplified in the 1922 hearings has never really disappeared. Today miners readily admit, at least in private, to differences of opinion among themselves on how to solve these problems. But these differences have, in the last two decades or so, been almost completely papered over as the entire industry faces what it considers to be an overriding threat from outside its ranks, in the form of environmental protection advocates. ${ }^{16}$

The high point of environmental advocacy came in 1977, after several years of debate that centered around the reform recommendations put forward by the Public Land Law Review Commission. ${ }^{17}$ The pieces were thought to have fallen into place when the Carter Administration, dedicated to substituting a leasing system for the Mining Law's claim location system, took office and sought to connect with Henry Jackson, Chair of the pertinent Senate Committee, and Morris Udall, his House counterpart, both of whom had been advocating a similar approach.

In retrospect, this leasing proposal reached too far, without sufficient groundwork being laid with the industry. Facing a torrent of other pressing environmental business, and a recall effort ${ }^{18}$ by disgruntled miners in his district, Congressman Udall backed off, and reform efforts collapsed with surprising speed. ${ }^{10}$

13. The Mining LAw, supra note 4, at 95-107. These problems are compounded by the fact that, as a recent study succinctly put it, "[i]mproved geophysical, geochemical, and geologic tools have revolutionized mineral exploration since World War II." R. EGGERT, METALlic Mineral ExPLORATION 5 (1987). This study also noted that because "the Western United States [has] been searched relatively intensely,. . the likelihood that conventional prospecting will play much of a role in future discoveries [is reduced]." Id. at 7.

14. THE Mining LAw, supra note 4, at 169-79.

15. Id. at $93-95,179-81$.

16. Id. at 301-04. For an interesting view of the modern small miner subculture, see CONAWAY, The KINGDOM IN THE Country 82-92 (1987).

17. The Mining Law, supra note 4, at 301-04.

18. Although there is no mechanism in federal law for recalling a sitting congressman, the Arizona law provides for an "advisory" recall. 19 ARIz. REv. STAT. ANN. \$§ 221-22; see Leshy, The Making of the Arizona Constitution, 1988 ARIz. ST. L.J. 1, 106 n.673.

19. The Mining Law, supra note 4, at 304-05. Ironies pervade these developments. Udall had come to embrace a leasing system for hardrock minerals before Jackson. Both had served on the Public Land Law Review Commission. Jackson had supported the majority's recommendation for retaining 
Although a spate of reform proposals had been introduced in Congress every year since 1970 , so thorough was the retreat that no new bills to reform the Mining Law were even introduced after 1978. For his part, Ronald Reagan has presided over the first Administration to fail to advocate legislative reform of the Mining Law since a mining engineer, Herbert Hoover, occupied the White House. ${ }^{20}$ After its swift disappearance from the congressional agenda, a new generation of Representatives and Senators assumed office, happily ignorant of the Law, its colorful history, and the pitched battles over its reform that had commanded so much attention just a few short years earlier.

\section{STIRRINGS OF REFORM-1985-1988}

The remarkable revival of interest in Mining Law reform since 1985 results from the confluence of several disparate events. First, the unproductive litigation to which the Mining Law has always been prone has continued apace, highlighting the statute's shortcomings as an engine of mineral development. The best illustration was furnished by a Nevada federal district court's 1987 decision in Amax Exploration v. Mosher, ${ }^{21}$ which resolved a legal battle between rival Mining Law claimants by holding that neither group had any legal rights against the federal government (which owned the land in question), nor against each other. The net result of all their efforts spent to locate and litigate these claims was exactly zero. The decision was not an aberration; on the contrary, it

the location system with some modifications, largely in the interest of comity with Commission Chair Wayne Aspinall. Jackson did, along with some other Commissioners, insist that the Report's transmittal letter to the President state that "the absence of a member's separate views does not necessarily indicate that there is unanimity on the details." Letter from D. Michael Harvey, Chief Counsel, United States Senate Committee on Energy and Natural Resources to John Leshy (June 7, 1988) (copy on file with The Public Land Law Review). Morris Udall had, with three other Commissioners, dissented and advocated the leasing substitute. Udall's brother Stewart left office in January 1969 describing the Mining Law as an "antique in need of repeal," calling it the "most important piece of unfinished business on the Nation's natural resource agenda." THE MINING LAW, supra note 4, at 302. Within three years after Stewart's blast, and publication of the PLLRC report, Jackson had become a radical reformer, embracing a leasing system as more consistent "with his belief in land use planning with broad public participation as the foundation for federal land management." Letter from D. Michael Harvey, supra this note.

20. While not all administrations since Teddy Roosevelt's have advocated reform of the Mining Law, all who have considered the question before the current one have at least acknowledged its defects. See The Mining LAw, supra note 4, at 289-310. In sharp contrast, the Reagan Administration's leading spokesperson on Mining Law issues, Assistant Secretary of the Interior Steven Griles, recently described the Mining Law as "working well." Interview with Steven Griles, December 16, 1987, conducted by Public Land News, at 10 (copy on file with The Public Land Law Review). Griles firmly opposed legislative reform on the ground that it would inevitably result in increasing "unnecessary environmental standards and requirements" that the country could not afford "in a time of a shortage of strategic and critical materials." Id.

21. Civ. No. R-85-162 BRT (D. Nev. March 2, 1987). 
was a careful and conscientious reading of existing law. ${ }^{22}$ It poignantly underscored how the statute prevents sensible business people from taking sensible steps to add to the nation's mineral wealth. ${ }^{23}$

Second, the recent revival in the markets for some hardrock minerals, particularly gold and a few other precious metals, have put more pressure on the statute. The Mosher litigation itself took place in a new hotspot of Mining Law activity, for gold and associated minerals in Nevada. In fact, domestic gold production increased by nearly $50 \%$ in 1986, with some forty new mines opening. ${ }^{24}$ Mining Law reform was largely an irrelevancy when the hardrock industry was fighting for its very life, battered by high production costs, foreign competition, and depressed demand. Today, on the other hand, reform is worth arguing about because of renewed interest in producing domestic supplies of at least some hardrock minerals, albeit with a leaner, restructured industry. ${ }^{25}$

Third, some industry groups and their allies have begun to take another look at the reform question, and to ask publicly whether the time might be ripe for a renewed effort toward legislative reform, even to the point of entertaining the possibility of face-to-face negotiations with environmental groups. The Minerals Exploration Coalition (MEC) has emerged as a leader here, along with the Public Resource Foundation, a small, independent think-tank with ties to a segment of the industry. ${ }^{28}$ The willingness of these groups to go public with their discontent over the current state of affairs opened a wedge in industry ranks, and undermined

22. See The Mining Law, supra note 4, at 95-107, 158-63.

23. My book recounts a number of these lengthy court fights. One, the infamous "Foresyth Saga," see id. at $457 \mathrm{n} .177$, has recently been the subject of yet another administrative decision that may help bring the matter to a conclusion after more than 20 years. See U.S. v. Foresyth, 100 IBLA 185 , GFS (MIN) 20 (1988). For a practitioner's recent view of the difficulties of dealing with the uncertainties of the Mining Law, see Hubbard, Drafting Private Agreements Relating to Public Lands, Natural Resources and Environment 9 (Winter 1988).

24. Department of the Interior News Release, January 9, 1987 (copy on file with THE PubliC LAND LAW REviEW). The release did not indicate how many of these new mines were on federal land subject to the Mining Law. For a summary description of the development of several Nevada gold mines in the modern era, see Oversight Hearing on the Mining Law of 1872 Before the Subcomm. on Mining and Natural Resources of the House Comm. on Interior and Insular Affairs, 100th Cong., 1st Sess. 348-52, 357-63 (1987) (testimony of Graham M. Clark, Jr., on behalf of the American Mining Congress) [hereinafter cited as Oversight Hearing].

25. Total employment in the metal mining, steel, and primary nonferrous metals industry dropped from 628,000 to 342,000 between 1980 and 1986. U.S. DEPT. OF THE INTERIOR, THE Mineral Position of the UNited States-1987 at 12 (Annual Report of the Secretary of the Interior Under the Mining and Minerals Policy Act of 1970). Foreign investment in the U.S. industry doubled between 1977 and 1984, $i d$. at 18, and the cost of producing a pound of copper dropped from 79 cents to 54 cents between 1981 and 1986. Id. at 8. Nevertheless, the copper industry still faces strong competition from abroad. See Comment, The United States Copper Industry in the World Market: Running Hard Yet Losing Ground, 8 NoRTHWestern J. INT. LAw AND Business 686 (1988).

26. Oversight Hearing, supra note 24, at 91-179, 191-244. 
the unyielding opposition to any reform advocated by the flagship trade association, the American Mining Congress. ${ }^{27}$ In fact, the MEC commissioned a poll of its members that showed a substantial minority favored at least discussing reform. ${ }^{28}$ Congressman Nick Rahall, Chairman of the pertinent Interior Committee subcommittee ${ }^{29}$ called the poll results an indication of "a progressive faction within the mining community" that recognizes the Mining Law "is no longer conducive to the efficient exploration and extraction of hardrock minerals on public domain lands." 30

Fourth, corresponding signs of flexibility emerged among some environmental groups. For example, the National Wildlife Federation, the nation's largest membership group concerned with environmental issues, signaled a willingness to discuss Mining Law reform that did not involve conversion to a pure leasing system. ${ }^{\mathbf{3 1}}$ Congressman Rahall swiftly hailed these signs of flexibility as enhancing the possibility of compromise, arguing that "the time is now ripe for serious discussions to take place between the environmental community and industry."32

Fifth, segments of the industry and environmental groups successfully resolved one local dispute by negotiation, demonstrating that compromise was possible between historically conflicting interests. Energy Fuels Nuclear was actively engaged in exploration on the Arizona Strip (that part of Arizona north of the Grand Canyon) for uranium concealed in rich, breccia pipe deposits. It struck a compromise with environmental groups (led by the National Wildlife Federation and the Wilderness Society) on wilderness designation for parts of the Strip. The agreed-upon legislation, the product of months of face-to-face meetings between the two camps (with the Bureau of Land Management watching from the sidelines), was

27. Id. at 326 .

28. See 133 Cong. Rec. E4779-80 (daily ed. Dec. 11, 1987).

29. Congressman Rahall is from West Virginia, where the Mining Law does not operate-a not insignificant fact because it makes him less subject to pressure from the Western states where the law does apply. One of his predecessors who was similarly interested in reform in the early 1970's, Patsy Mink, hailed from Hawaii, where the Mining Law also has little or no application.

30. Id. Congressman George Miller, another influential member of the House Interior Committee, scored the American Mining Congress's inflexibility while addressing that group's annual meeting in the fall of 1987. See 133 CoNG. REC. E3653 (daily ed. September 22, 1987).

31. Oversight Hearing, supra note 24, at 244-76, 295-321.

32. 133 CONG. REC. E2583-84 (daily ed. June 25, 1987). For recent op-ed commentaries on the need for Mining Law reform, see Charles Callison (formerly with the National Audubon Society and the Public Land Institute of the Natural Resources Defense Council), The Nation's Obsolete Mining Law, St. Louis Post Dispatch, July 20,1987, at 18, col. 1; see also Sandra Blackstone (former Deputy Director of BLM for Energy and Mineral Resources in the Reagan Administration), Old Mining Law Played Out, Rocky Mountain News, July 5, 1987, at 57, col. 1. For editorial support for reform, see $A$ New, Old Scar, Arizona Daily Star, Dec. 6, 1987, at 18, col. 1 (calling the law "outdated" and "awful" that produces "evils"); see also A Noble Task, Arizona Daily Star, March 11, 1987, at 14A, col. 1. 
swiftly folded into the Arizona Wilderness Act of $1984 .{ }^{38}$

Sixth, the Reagan Administration unwittingly fueled the fires of reform by settling quarter-century-old litigation challenging mining claims for oil shale. These claims had been located in the early part of this century, and were exempted from the Mineral Leasing Act of 1920, which generally made oil shale leasable, not locatable. ${ }^{34}$ Although these grandfathered claims had remained dormant ever since, the administration agreed to patent claims to 82,000 acres of federal land, with some restrictions, and to dismiss its appeal of an adverse district court decision that had resolved most legal questions about the validity of these claims in favor of the claimants. ${ }^{35}$

Probably more than any other single act, this settlement brought Mining Law reform back into the public eye. ${ }^{36}$ The specter of a "giveaway" of large tracts of federal land for a per-acre price of a fast-food hamburger under this antique law galvanized Congress into action-not yet completed-to stop further patenting of oil shale claims. ${ }^{37}$ It also had the effect, more important over the longer term, of educating a new generation of legislators about the Mining Law..$^{38}$

Seventh, the National Wildlife Federation (NWF) brought litigation, so far successful, challenging the Department of the Interior's program to revoke withdrawals of federal land from the Mining Law, and classifications of federal land that restricted their use for hardrock mining. ${ }^{39}$ The suit contends that the program's implementation is not in

33. Pub. L. No. 98-406, $\S \S 301-04,98$ Stat. 1485, 1492-94 (1984). See H. R. Rep. No. 98-643, Part I, 98th Cong., 2d Sess. 34-40.

34. See 30 U.S.C. $\$ 193$ (1982); see also THE Mining LAw, supra note 4, at 114-15, 320.

35. Tosco Corp. v. Hodel, 611 F.Supp. 1130 (D. Colo. 1985). See generally Oil Shale Claims, Hearing Before the Subcomm. on Mining and Natural Resources of the House Comm. on Interior and Insular Affairs, 100th Cong., 1st Sess. 1-2, 15-43 (1987) [hereinafter cited as Oil Shale Hearing].

36. The history of the Mining Law is so rich that one can find a precedent for almost anything. The current controversy over .jil shale claims brings to mind a spate of publicity over abuse of the Mining Law in the early 1950's that led Congress to constrict the Law's applicability to widely occurring minerals like sand and gravel, and to strengthen the executive's regulatory power over mining to protect other resources. See The MinING Law, supra note 4, at 67-71. Students of history might also take note that a Department of the Interior decision to issue patents to disputed mining claims in Oregon to the Al Serena Company in January 1954 became a major political issue in the 1956 elections. After an investigation revealed that the company had cut two million board feet of timber and engaged in no mining, the episode fueled Democratic charges of a Republican "giveaway" of the nation's resources and led to the defeat of former Secretary of the Interior Douglas McKay in his bid for a Senate seat from Oregon. See E. Richardson, Dams, Parks \& Politics 167-70, 177 (1973).

37. Another 270,000 acres of federal land are subject to similar claims, but were not part of the settlement. The House passed the bill June 2, 1987. See 133 CoNG. REC. H4083-86 (daily ed. June 2, 1987).

38. For example, only eight of the nineteen Senators currently serving on the Senate Committee on Energy and Natural Resources, which has jurisdiction over the Mining Law, were in Congress the last time Mining Law reform was seriously debated, in 1977.

39. National Wildlife Federation v. Burford, 676 F.Supp. 271 (D.D.C. 1985), 676 F.Supp. 280 
compliance with the National Environmental Policy Act ${ }^{40}$ and the procedural requirements of the Federal Land Policy and Management Act. ${ }^{41}$ The lawsuit has stymied the Department's and industry's efforts to open up additional federal land to the Law. Moreover, it has kept a spotlight on the Law itself. Executive withdrawals have always been a favorite device to limit access under the Mining Law, ${ }^{42}$ because they give the executive almost unlimited discretion to decide where the Law will apply -in effect, to repeal the law by fiat for particular tracts of land. ${ }^{43}$ Modern courts have consistently rejected challenges to such withdrawals. ${ }^{44}$

The principal reason underlying many withdrawals from the Mining $\mathrm{Law}^{4 \mathrm{~s}}$ is to thwart that feature of the Mining Law-the so-called mineral patent-that gives claimants the opportunity to obtain fee simple title to the land. ${ }^{46}$ Loss of title to particular areas maybe an unacceptable risk to agency management objectives, even when mining itself is not. The agencies have always regarded themselves as powerless, without legislation, to withdraw land just from operation of the patent feature. Instead, withdrawal is an all-or-nothing proposition-an area of land is either completely open or completely closed (subject to valid existing rights) to the Mining Law. ${ }^{47}$ Revoking existing withdrawals, correspondingly, means opening the land up to possible patenting and transfer into private ownership.

Revoking withdrawals of federal land from the Mining Law also brings to the fore another environmentalist criticism of the Law-that it

(D.D.C. 1986), aff d, 835 F.2d 305 (D.C.Cir. 1987). The "classifications" at issue were made by BLM during the six year life of the Classification and Multiple Use Act of 1964, Pub. L. No. 88-607, 78 Stat. 986 (1964), which expired by its own terms in 1970. See Pub. L. No. 90-213, \$2,81 Stat. 660 (1967). In the interest of brevity the term "withdrawal" shall be used to embrace "classifications" as well.

40. 42 U.S.C. $\$ \S 4321-61$ (1982).

41. 43 U.S.C. $\$ \$ 1701-82$ (1982).

42. Oral argument was recently held in the district court on whether to make permanent the injunction against withdrawal revocations and reclassifications unless NEPA and FLPMA are complied with. See 13 Public Land News 1-2 (Aug. 4, 1988).

43. See The Mining LAw, supra note 4, at 31-43.

44. See, e.g., Pathfinder Mines Corp. v. Hodel, 811 F.2d 1288 (9th Cir. 1987); Shiny Rock Mining Corp. v. United States, 825 F.2d 216 (9th Cir. 1987); $c f$. Mountain States Legal Found. v. Hodel, 668 F.Supp. 1466 (D. Wyo. 1987) (holding that a general failure to act upon mineral lease applications in a specific area is a withdrawal that can only be effected through withdrawal procedures required by law); Mountain States Legal Found. v. Andrus, 499 F. Supp. 383 (D. Wyo. 1980).

45. Withdrawals are also possible from the Mineral Leasing Act and several other federal statutes authorizing "settlement, sale, location, or entry" of the federal lands for various purposes. 43 U.S.C. $\$ 1702(\mathrm{j})(1982)$.

46. 30 U.S.C. $\$ 29$ (1982).

47. See The Mining LAw, supra note 4, at 41-43. An interesting question is whether the Department could revoke a withdrawal in part, to allow claim location and development without patenting. Although the patent is an express part of the Law, the Supreme Court's decision in United States v. Midwest Oil, 236 U.S. 459 (1915), deferred substantially to the executive branch's efforts to limit its scope in the face of seemingly clear statutory language to the contrary. 
does not allow the kind of tight administrative regulation to protect the environment that is possible under the Mineral Leasing Act and other statutes permitting development of federal land resources. While environmental regulation has come, somewhat belatedly, to operations conducted under the Mining Law, the land management agencies have been rather timid about enforcing them, out of concern for adversely affecting the "right to mine" which they see as embedded much more deeply in the Mining Law than in the Mineral Leasing Act. ${ }^{48}$ The NWF lawsuit, in other words, highlights some of the ways in which the Mining Law is perceived to be out of step with modern environmental imperatives.

Eighth, the pertinent House subcommittee weighed into the fray by holding an oversight hearing on the Law in June $1987 . .^{49}$ The hearing, the first in a decade on the Mining Law, served an educational function, and helped establish some modest momentum toward consideration of reform. In his statement at the beginning of the hearing, full Committee Chairman Udall did not warm to the idea of legislative reform. ${ }^{.0} \mathrm{He}$ adverted to the American Mining Congress' attempt to derail the hearings for fear it was a "first step to legislative change." 11 Udall denied that the hearing was "intended as a forerunner to either a leasing system or to other changes in the law." 32 On the other hand, Udall had a few months earlier written the AMC that "it is getting more and more difficult to maintain" the Mining $\mathrm{Law}^{\mathrm{s3}}$ and he observed at the hearing that while he was not "aiming at legislative changes at this time. . . [t] hat is not to say that some changes are not needed or that changes will not be made." served to increase the possibility that legislative reform might be pursued, even though no reform measures have, to date, been drafted or introduced.

\section{Possible Scenarios for Legislative Movement}

A hoary maxim of life on Capitol Hill is that Congress acts only where there is either a crisis or a consensus. Currently there is no genuine crisis involving hardrock mining, but with a little effort crises sufficient to bring about reform might be imagined. Some would benefit the mineral industry; others, environmental advocates. Sudden loss of supply of a particular

48. The Mining LAw, supra note 4, at 224-25. This is not to say that the executive lacks the authority to achieve tighter environmental controls without statutory reform; the problem may only be one of will, not power.

49. See Oversight Hearing, supra note 24.

50. Id. at 11-14.

51. Id. at 12 .

52. Id.

53. Letter from Cong. Morris Udall to AMC President John Knebel (January 29, 1987), quoted in Public Land News 1, March 5, 1987.

54. Oversight Hearing, supra note 24, at 13. 
mineral, stemming perhaps from the embargo of a foreign source of supply for a strategic mineral, might create an emergency sufficient to spur Congress to reform the Mining Law to facilitate the development of domestic sources of supply. On the other hand, identification of some major previously unappreciated environment problems with mines might spur Congress to reform the Mining Law with the opposite objective, of curtailing rather than enhancing mineral production.

Some particularly dramatic episode that highlights the peculiar anachronisms of the Mining Law might also encourage Congress to perform surgery on the Law. Indeed, the settlement of the oil shale claims litigation furnishes an example, at least in the narrow context of these grandfathered oil shale claims. ${ }^{\mathrm{ss}}$

Bold administrative actions like major new withdrawals, creative rulemakings, and aggressive environmental enforcement could force Congress's hand. Presidential withdrawals of large tracts of federal lands from the Mining Law ultimately led, after all, to enactment of the Mineral Leasing Act. ${ }^{58}$ Congress has, in modern times, enacted procedural controls on the executive's use of the withdrawal tool. ${ }^{.7}$ These should not, however, obscure the fact that Congress has effectively confirmed an expansive application of the executive's substantive power to make withdrawals, by its 1976 repeal of the 1910 Pickett Act's prohibition of withdrawals from "metalliferous" minerals. ${ }^{88}$ Legislative-forcing steps by the executive branch may not be without political costs, but tools remain available to an administration determined, as Presidents Roosevelt and Taft were, to bring about Mining Law reform.

Although various crises are imaginable, none are looming on the horizon. Their absence leaves consensus as the more realistic avenue for achieving reform. If important segments of industry and environmental groups could arrive at a compromise, it could be translated into legislation.

There is some room for optimism here because a number of reform desiderata on each side are not items the other side would greatly resist. Industry, for example, would like the limits on claim size to be enlarged, the distinction between lode and placer claims abolished, and, most important,

55. See supra text accompanying notes 34-38.

56. The Mining LAw, supra note 4, at 32-34. Defenders of the Mining Law who are touched with paranoia might see the Reagan Administration's oil shale claim patent settlement as designed to promote legislative reform, but available evidence suggests that the effect was unanticipated. The Administration has generally opposed legislative efforts to restrict patenting. See Oil Shale Hearing, supra note 35 , at $15-43$.

57. See 43 U.S.C. $\$ 1714$ (1982).

58. See 36Stat. 847 (1910), which prohibited withdrawals for minerals "other than coal, oil, gas and phosphates," but was narrowed in 1912 to include only "metalliferous minerals." 37 Stat. 497 (1912). This was repealed by $\S 704(\mathrm{a})$ of the Federal Land Policy and Management Act of 1976, 90 Stat. 2792 (1976). 
greater security of tenure during the exploration phase, especially against other claimants. None of these ought to excite much opposition from environmental groups. ${ }^{59}$

The reverse is also true. A number of things on an environmental wish list should not be life-and-death issues to the industry. These include the elimination of the surface patent, repeal of the so-called "uncommon varieties" provision that allows widely occurring, ordinary minerals like sand and gravel to be located under the Mining Law, ${ }^{60}$ stronger tools to deal with abuse of the Mining Law for non-mineral ends, ${ }^{61}$ and, perhaps, tighter or at least more consistent regulation of mining activities to protect the environment. ${ }^{62}$

Issues of cold cash-specifically, whether rents and/or royalties ought to be imposed on mining claimants and the minerals they produce-might be somewhat more complicated to resolve. The Mining Law's gift of free minerals and almost free land has long been subject to trenchant criticism, and practically all of the various reform proposals offered over the last two decades have included provisions for at least a rental charge for the land. ${ }^{63}$

Curing the Law's failure to require claimants to pay a rental, royalty or license fee has considerable political appeal, particularly in an era of large federal deficits and an increasing appetite for charging recreational and other users of the federal lands something for the privilege. Recognizing this political reality, the industry might show some flexibility on the issue, and it could become a bargaining chip. ${ }^{64}$ Because a mining claim typically changes hands several times before it is brought into production,

59. See THE MiNING LAw, supra note 4, at 365-66. The elimination of the extralateral rights feature of the Mining Law might be another welcome feature to at least some elements in the industry. Id. at 95, 288-89,300. For a recent case on the subject, unusual because it involved following a mineral vein onto Indian land, see Swoboda v. Pala Mining Co., 844 F.2d 654 (9th Cir. 1988).

60. See The Mining LAw, supra note 4, at 68-69; 30 U.S.C. $\$ \$ 611-15$ (1982).

61. This includes the colorful history of using the Mining Law as a cover for recreational cabins, exclusive occupancy of prime fishing sites, and so forth. See THE MINING LaW, supra note 4, at 55-61. The Forest Service has once again mounted an effort to combat what it calls "unauthorized occupancies" on mining claims in northern California. See NEwSWEEK 62, March 28, 1988. For recent reported cases of enforcement of environmental requirements, see United States v. Brunskill, 792 F.2d 938 (9th Cir. 1986); United States v. Nordwick, 673 F.Supp. 397 (D. Mont. 1987). In a recent decision holding that mining claims were not held in good faith, the Interior Board of Land Appeals described the claimants' activities as "no more than recreational," finding "no evidence. . .that during the 50 years of occupancy the [claimants] expended even a nominal amount of time and means in an effort to develop a valuable mine." U.S. v. McMullin, 102 IBLA 276, 283-84 (May 24, 1988).

62. The Mining LAw, supra note 4, at 367-68.

63. Id. at 302-04.

64. Id. at 366-67. Rumors abound that the current cost of producing an ounce of gold from the typical modern mine (of the so-called "Carlin-type" deposit in Nevada) is $\$ 200$, while the market price has been well over $\$ 400$ per ounce for some time. Such figures dramatize the anomaly of the Mining Law's gift. 
and because it is not uncommon for those in the chain of title to retain a royalty interest in the ultimate production, it could be relatively easy for the United States to impose an assignment or transfer fee, calculated as a percentage of any payments made to the transferee.

The issues where common ground might be found could supply the basis for establishing negotiating momentum, creating a climate favorable for compromise on what will probably prove to be the key to any reform effort-how to resolve the difference between the industry's staunch defense of the self-initiation, claim location system, and the environmentalists' equally fervent advocacy of a discretionary leasing system. ${ }^{65}$ At bottom the issue is usually characterized as whether the government ought to have the right to say "no" to hardrock mineral development. Environmentalists argue it should, pointing out that federal land managers have a right to veto practically every other use of federal lands. Industry argues against it on the ground that governmental discretion will inevitably lead to a lockup of federal lands from hardrock mining.

That polarization of views on the core issue of Mining Law reform has so far defined the terms of the debate, even though, as indicated earlier, some of the warring parties have signaled a willingness to be flexible.$^{68} \mathrm{~A}$ committed optimist could find room for hope here. At bottom, "leasing" and "self-initiation" are merely labels that often obscure how different mineral development systems actually operate. The Mineral Leasing Act is the leading example of the former, but until quite recently it was administered in such a way that it functioned much like a location system-leases were readily issued, usually on demand. ${ }^{67}$ The Mining Law is the leading example of the latter, but today it is administered in such a way that the government has (by means of withdrawals, land use planning, and environmental regulation processes) a substantial say in whether, where, and how hardrock mineral activity shall occur. ${ }^{68}$

The rhetoric employed in the modern debate over Mining Law reform is, in a word, inaccurate. The choice is not, as usually portrayed by environmentalists, one between all-out, unrestrained mineral activity and limited, carefully controlled mining. And it is not, as usually portrayed by industry, one between controlled mining and none at all.

Operations under the Mining Law are being brought, sometimes kicking and screaming to be sure, but brought nevertheless, into at least rough conformity with the environmental imperatives of the modern, post-

65. The Mining LAw, supra note 4, at 327-41. See also Oversight Hearing, supra note 24, at 185 (testimony of John D. Leshy).

66. See supra text accompanying notes 26-32.

67. The Mining LAw, supra note 4 , at 333.

68. Id. at $220-28,341$. 
Earth Day age. Most of the major environmental regulatory laws enacted since 1969, including the Clean Air and Clean Water Acts, the Endangered Species Act, and the National Environmental Policy Act, apply to activities conducted under the Mining Law. ${ }^{69}$ State and even local government regulatory measures are also playing a more important role. ${ }^{70}$ And looking down the road, it seems likely that the land use planning provisions of the Forest Service and Bureau of Land Management organic statutes will increasingly be used to restrict industry opportunities to use the Mining Law. ${ }^{71}$

Some of these laws will apply somewhat differently, and perhaps a bit less rigorously, to Mining Law activities than to other federal land uses that involve a purer form of agency discretion than the Mining Law. Nevertheless, the American Mining Congress (AMC) is basically correct when it characterizes the Mining Law today as occupying a "unique, but not preferred" place in the panoply of federal land uses. ${ }^{72}$ Indeed, lately the AMC has been touting the flexibility of the Mining Law in allowing accommodation to modern environmental values within its framework ${ }^{73}$ - a marked change in rhetoric from a few years ago when industry spokesmen argued that the Law may not permit much environmental regulation. ${ }^{74}$

The taming of the Mining Law from the standpoint of environmental protection is a significant development. It is also somewhat underappreciated, probably because it has occurred only in relatively undramatic increments rather than through boldly drawn changes. But there seems no going back; the trend toward more environmentally inspired restrictions seems irreversible.

The industry's rhetoric that discretion means no mining activity at all deserves similar skepticism. For many decades the government has possessed the power to say "no" to hardrock mineral development by withdrawing federal land from the Mining Law. This is not quite the same thing as denying an application for a mineral lease, and therefore makes environmentalists nervous, but it does illustrate that the discretion/no discretion paradigm is misleading. Moreover, experience under federal

69. Id. at 186-89. See also Oversight Hearing, supra note 24, at 365, 371-72. Another example is regulations recently promulgated by the Environmental Protection Agency under the Clean Water Act that impose substantial new costs on gold placer mines by requiring complete recirculation of process waste water. 53 Fed. Reg. 18764 (1988).

70. See infra text accompanying notes 105-08.

71. See infra text accompanying notes 102-04.

72. Oversight Hearing, supra note 24, at 386 (testimony of Jerry L. Haggard).

73. Id. at $389-90,410$.

74. See, e.g., Dempsey, Forest Service Regulations Concerning the Effect of Mining Operations on Surface Resources, 8 NAT. RES. LAWYER 481, 483-86, $492-96$ (1975). 
and state mineral leasing systems shows that lockups do not occur very often. ${ }^{78}$

The reason is not hard to pinpoint. There are strong political constraints operating against a hardrock mining deep freeze. Mining activity produces substantial economic benefits to local areas in the form of jobs, tax revenues for state and local governments, and a variety of secondary economic benefits. Some mining has national security implications. While it is true that changing cultural values have in effect shifted the burden of persuasion from opponents to proponents of mining in much of the West, ${ }^{76}$ it is difficult to argue that hardrock mining will disappear simply because government is given discretion to deny it. In fact, despite all the hand-wringing of recent years about the industry's loss of access to federal lands, a recent study concluded that it was "far from clear that U.S. federal and state policies [toward mineral exploration] have been on balance more onerous or restrictive than policies in other countries," and that "[i]ndeed the data, although admittedly weak, would even allow one to conclude that U.S. policies may be more favorable toward exploration than most." $" 77$

These gaps between rhetoric and reality ought to affect how the challenge of Mining Law reform is perceived. While there is political mileage to be gained in portraying the choice in bold terms-between mining or no mining (as the dominant industry opinion would have it), or as between unbridled exploitation and carefully managed development (as the dominant environmental opinion would have it), the truth is neither plain nor simple.

Instead, the politically realistic options boil down to a much narrower range of choice. For the industry, it is acquiescing in some loss of leverage in dealing with the government regulators in return for a much more sensible and orderly system of exploration and development. For the environmentalists, it is acquiescing in some continued role for industry initiative in gaining access to federal lands in return for stronger and more forthright environmental safeguards, especially against those who abuse the Law and the landscape.

I am not so optimistic as to expect accommodation between these two camps to be easily fashioned. They have been bitter foes for decades, and the gulf between them is wide. They have tended to speak different languages, reflecting their radically different approaches to basic issues. And they have dug in rather deeply in their respective positions. But one can detect a softening of rhetoric and a more genuine attempt to

75. The Mining LAW, supra note 4, at 327-41.

76. See J. Leshy, Mining's Diminished Future, High Country News (Oct. 24, 1988).

77. R. EGGERT, supra note 13, at 27, 29. 
understand differing perspectives in recent years. Some mining enterprises have demonstrated a real commitment to environmental protection, especially if they are fortunate to have found deposits rich enough, and enjoy profit margins wide enough, to bear the additional expense usually entailed. And some environmentalists have come not only to recognize these commitments, but also to recognize the economic benefits of mining where it does not unduly threaten special values such as those found in parks or wilderness.

Writing on a clean legislative slate, one could, without a great deal of difficulty, design a leasing system that operated much like a location system, or vice-versa. Foreign jurisdictions such as the Canadian provinces provide some useful approaches. ${ }^{78}$ Creative thinking and good-faith bargaining could produce a compromise that allows both interests to save face and arrive at a result that could be, if not fervently embraced, at least grudgingly accepted.

\section{Stumbling Blocks to a Negotiated Settlement}

Assuming that a substantive basis might be found for a negotiated solution to the reform conundrum, two other pitfalls bear mentioning. The first goes to the threshold question of whether to enter negotiations at all. Some genuinely fear that negotiations will lead to loss of control, and are haunted by the specter of their agreements on some issues being used against them. This is most obvious in the American Mining Congress' staunch opposition to any and all reform efforts, which appears bottomed on the belief that once the legislative train starts moving, the industry will have no control over where it will end. ${ }^{79}$ If industry signals a willingness to compromise on some issues but not others, it may have an unacceptable solution imposed upon it. Therefore, the only safe course is not to negotiate anything.

The fear cannot be discounted. The legislative process has a life all its own, and is notoriously difficult to manage. This fundamental characteristic of political bargaining was illustrated by the fact that it took eight years to repeal the so-called "two acre" exemption from the Surface Mining Control and Reclamation Act, even though environmental groups and major industry players fairly quickly agreed that it ought to be repealed. ${ }^{80}$ But neither side was very willing to risk opening up that law, so bitterly contested in the first place, to other amendments that might prove

78. See, e.g. 6 AMERICAN LAw of Mining, Chapter 213 (2d ed. 1987), describing generally the Canadian provincial approaches.

79. See Oversight Hearing, supra note 24, at 179, 322-412.

80. 30 U.S.C. $\$ 1278$ (1982) amended by Pub. L. No. 100-34, Title II, $\$ 201$ (a), 101 Stat. 300 (1987); see generally 1987 U.S. CODE CONG. AND AdmIN. NEws 256, 258-59, 264-65. 
mischievous or disadvantageous to either.

As this example suggests, however, the dilemma is one shared by both sides. Legislative gridlock extending over a score of years ought to be sufficient to demonstrate that the political power of the industry and the environmental groups on Mining Law reform is so relatively evenly divided that neither can control the legislative process. While it is industry that most often voices this concern, environmentalists can point to recent experience with reform of the oil and gas provisions of the Mineral Leasing $\mathrm{Act}^{81}$ as an example of their own lack of control over the legislative process where mineral development is concerned. When reform efforts began in earnest in the late 1970's as a result of recurring scandal in the operation of the federal oil and gas leasing lottery, environmentalists had high hopes of strengthening environmentally-oriented land use planning in any new system adopted. In the end, however, they failed. Congress failed to adopt their approach, calling instead merely for further study of the issue. ${ }^{\mathbf{2 2}}$

Progress is practically impossible without some risk, and potential negotiators could take solace in the well-worn truth that it is far easier to stop legislation from being enacted than to enact it. Because both sides stand an excellent chance of stopping reform legislation if the political process begins to spin out of control, the risk is not a grave one.

One other crucial, potentially fatal problem remains: How to deal with those nearly two million existing mining claims that dot the federal lands like so much confetti. I argued in my book that Mining Law reform is cosmetic if it is wholly prospective; that is, if it does not apply to existing claims. ${ }^{88}$ These claims blanket most areas of mineral potential, and abusive or nuisance claims would, if they survived reform, remain as potential roadblocks to mineral development and to sound management of federal lands for other purposes.

The problem of applying reform measures to existing claims is not really a legal, or constitutional, one. There are any number of ways for these claims to be converted to leases, or even extinguished, without posing problems of unconstitutionally "taking" private property interests without compensation. A number of modern court decisions, including several from the United States Supreme Court, make plain that the government's interest in ridding its lands of stale, inactive, nuisance, or abusive claims is generally strong enough to overcome the loss of whatever modest property

81. Pub. L. No. 100-203, 101 Stat. 1330-262 (1987), 30 U.S.C. $\$ 226$ note.

82. See id., $\$ 5111$. The study, for which Congress specified no completion date, is to be conducted jointly by the National Academy of Sciences and the Comptroller General. On the other hand, the same act did cement into law a general prohibition on leasing oil and gas in nearly all wilderness and wilderness study areas on federal land. Id., \$ 5112, amending the Mineral Leasing Act of $1920, \S 43$.

83. The Mining LAw, supra note 4 , at 313-25. 
interests might exist in them. ${ }^{84}$

Even claims supporting genuine "discoveries" or active mining operations could be converted to leases and subjected to broader regulation, so long as some opportunity to mine is protected, within relatively broad limits. The heightened environmental sensitivity of the modern era has combined with a century-old line of decisions allowing the abatement, without compensation, of what amount to public nuisances to vest the government with broad power to regulate mining activity without running afoul of the Constitution. ${ }^{85}$ The Surface Mining Control and Reclamation Act placed major new constraints on thousands of private property interests in coal, but the Supreme Court rejected without dissent, and without blinking, facial takings challenges to the act. ${ }^{86}$

The core property right in an unpatented mining claim is the opportunity to engage in mineral activity ${ }^{87}$ As the Supreme Court put it in 1978 , the Mining Law "surely was not intended to be a general real estate law." ${ }^{88}$ In constitutional terms, the form of the property right-whether claim, lease, permit, contract, or something else-is not controlling. What the constitution protects is the essence of the property right, and in a mining claim, it is only that opportunity to mine in a manner that does not seriously endanger other important values.

The hardrock industry has tended to respond to the host of modern cases recognizing the substantial regulatory power of government with the argument that the Mining Law is different. Under this view, the property rights that reside in existing mining claims have a special immunity from regulation that other, more ordinary property interests lack. It is true that, as the Supreme Court has several times said, unpatented mining claims are a "unique form of property."

84. See, e.g., United States v. Locke, 471 U.S. 84 (1985); Texaco v. Short, 454 U.S. 516 (1984); Alaska Miners v. Andrus, 662 F.2d 577 (9th Cir. 1981).

85. See e.g., Keystone Bituminous Coal Co. v. DeBenedictus, 107 S.Ct. 1232, 1243, 1244 (1987), quoting Block v. Hirsh, 256 U.S. 135, 155 (1921), and Mugler v. Kansas, 123 U.S. 623, 668-69 (1887). For an example of how the lower courts are interpreting Keystone, see Allied-General Nuclear Services v. United States, 839 F.2d 1572, 1576-77 (Fed. Cir. 1988), cert. pending, 57 U.S.L.W. 3095 (Aug. 9, 1988) ("The Supreme Court [in Keystone] has dusted off Mugler and put it back on its pedestal, while reducing Pennsylvania Coal Co.v. Mahon [260 U.S. 393 (1922)] as a precedent pretty much to its own peculiar facts").

86. See Hodel v. Virginia Surface Mining and Reclamation Ass'n, 452 U.S. 264, 295-97 (1981); Hodel v. Indiana, 452 U.S. 314, 333-35 (1981).

87. See e.g., Chambers v. Harrington, 111 U.S. 350, 353 (1884). See also Oversight Hearing, supra note 24, at 408 (testimony of Stanley Dempsey on behalf of the American Mining Congress, noting that mining companies "don't often patent mining claims. . . . [W]e don't need to patent mining claims in order to finance a mine [and] many. . . mines will operate through their whole life and never be patented").

88. Andrus v. Charlestone Stone Products Co., 436 U.S. 604, 611 (1978).

89. See, e.g., Best v. Humboldt Placer Mining Co., 371 U.S. 334, 335 (1963). 
on the fact that they are, until a patent is obtained, a mere possessory interest in federal land) cuts in favor of, rather than against, the government's exercise of broad supervisory powers over land to which it still holds title.

This was recently underscored in the Supreme Court's 1985 decision in United States v. Locke, ${ }^{80}$ upholding the recordation and annual filing requirements of the Federal Land Policy and Management Act. The Court began by observing that the government has the power, "with respect to vested property rights,. . . to impose new regulatory constraints on the way in which those rights are used, or to condition their continued retention on performance of certain affirmative duties."'11 Such new requirements pass constitutional muster if they are "reasonable" and "designed to further legitimate legislative objectives." "Significantly, the Court went on to say that this power "to qualify existing property rights is particularly broad with respect to the 'character' of the property rights [there] at issue"- unpatented mining claims. ${ }^{93}$ Specifically, the United States retains "substantial regulatory power" over mining claims because, as holder of the underlying fee title, it "maintains broad powers over the terms and conditions upon which the public lands can be used. . .and acquired." ${ }^{\prime 24}$ In short, mining claims are unusual property interests, but the very features that make them unusual strengthen rather than weaken the power of government to restrict their use in the public interest. For that reason, it is not surprising that modern courts have generally had little difficulty rejecting mining claimants' takings arguments in a variety of contexts. ${ }^{95}$

The real problem in dealing with existing claims is whether Congress can muster enough political support to subject existing claims to whatever new regime is adopted. But describing the problem as merely political scarcely denigrates its importance. One need only to look at the current controversy over patenting oil shale claims to be reminded of the difficulty

90. 471 U.S. 84 (1985).

91. Id. at 104.

92. Id.

93. Id. (emphasis added).

94. Id. Although three Justices dissented, they did so solely on non-constitutional grounds; that is, they did not contest the majority's view of Congress' power over unpatented mining claims.

95. Freese v. United States, 6 Cl. Ct. 1 (1984), aff d mem. 770 F.2d 177 (Fed. Cir. 1985) (Forest Service regulatory actions not so severe as to extinguish the essential attributes of plaintiff's property rights in unpatented mining claims); Skaw v. United States, $13 \mathrm{Cl}$. Ct. 7 (1987), aff d, 847 F.2d 842 (Fed. Cir. 1988), cert. denied, 57 U.S.L.W. 3220 (U.S. October 4,1988) (plaintiff did not demonstrate that valuable deposits of gold existed on his claims prior to withdrawal of the land from the Mining Law, so he had no constitutionally-protected property interest in the claims); Cascade Development Co. v. United States, $14 \mathrm{Cl}$. Ct. 651 (1988) (plaintiff's claim for compensation for loss of access to its patented mining claims within a designated wilderness area dismissed because the Forest Service had not rendered a final decision denying plaintiff access). 
Congress encounters when it comes up against arguments that expectations need to be honored. That controversy originated in the second decade of this century when Congress came to address proposals to take oil, gas, and other fuel and fertilizer minerals out from under the Mining Law. It agonized for seven years about how to treat existing mining claims for these minerals. ${ }^{98}$ In the end, it punted, grandfathering in these old claims by protecting them from the new leasing regime adopted in the Mineral Leasing Act of 1920, at least to the extent these claims were deemed valid and otherwise maintained in compliance with the Mining Law. ${ }^{97}$ Congress was, in other words, politically unable to overcome the resistance of these claimants.

As a result, mining claims located prior to 1920 for oil, gas, oil shale and the like, can today still be found on the federal lands, and are still governed by the Mining Law, even though for 68 years such minerals have otherwise been managed under the Mineral Leasing Act. It was for some 82,000 acres of grandfathered oil shale claims that the Reagan Administration issued patents in 1986, a decision that sparked current legislative efforts to repeal the right to patent. ${ }^{98}$ The House of Representatives has passed such a bill, ${ }^{98}$ but it is currently being held up in the Senate Committee on Energy and Natural Resources by Wyoming Senator Malcolm Wallop, who relies on the extravagant concern that repeal of the patent provision takes property rights. ${ }^{100}$

Two lessons emerge from this experience. First, the problem of existing claims will be difficult to solve politically. Second, it is crucial that such claims not be exempted from any reform measure, if we are to avoid a similar, long-lived legacy from Mining Law reform, 1980's style. Optimistically, if the oil shale legislation were to pass in something like its current form, it would furnish a convenient model for the Congress to use if and when it comes to address the existing claims problem in general reform of the Mining Law.

96. The Mining LAw, supra note 4 , at 322.

97. See supra note 34 .

98. See supra notes 35-36.

99. The House vote on final passage of this bill might provide some clues to political votecounters as to the support general revision of the Mining Law might command. No Democrat voted against the bill, while more than sixty Republicans, all from outside the eleven Western states, broke ranks to support the bill, which passed 295-93. 133 CONG. REC. H4085-86 (daily ed., June 2, 1987).

100. See Oil Shale Mining Claims Conversion Act Hearing Before the Subcomm. on Mineral Resources Development and Production of the Senate Comm. on Energy and Natural Resources, 100th Cong., 2nd Sess. $62-67$ (1988). See also id. at 96-119, 230-33 (statement of John D. Leshy). Congressman Morris Udall recently asked the House Appropriations Committee's Subcommittee on Interior to include in the fiscal year 1989 appropriations bill a prohibition on patenting oil shale claims, as a way around the Senate's foot-dragging on the oil shale legislation. 13 Public LANDS NEws 5-6, May 26, 1988. 


\section{The Future Without Comprehensive Reform of the MINING LAW}

To round out the picture, it is worth sketching out what might reasonably be expected to occur absent comprehensive legislative reform of the Mining Law. In actual practice, the statute has steadily evolved since 1872 , and that evolutionary process will not stop. Its direction seems plain and, realistically viewed, provides scant comfort for the already embattled hardrock industry. Put another way, it seems likely that industry has more to fear from lack of reform than the environmentalists.

For one thing, there will likely be continuing focus on withdrawals and withdrawal revocations, with more of the former than the latter. Withdrawals will come through enactment of new protective legislation, especially wilderness designations. And the executive branch will probably use its own withdrawal powers to protect particular areas of special value from the Mining Law. Indeed, it seems reasonable to expect that the Forest Service and the BLM will increasingly use their land and resource planning processes as the primary vehicle for assessing withdrawals, in deciding both whether to extend or revoke existing ones, and to make new ones. Withdrawal revocations are currently tied up in the National Wildlife Federation lawsuit, ${ }^{101}$ which seems likely to succeed, at least in part, and will in any event apparently drag on at least until a new Administration takes office.

Second, the Forest Service and the BLM will probably use their planning processes more frequently to impose site-specific restrictions on hardrock mining activity. These processes allow the land managing agencies to become much more active than reactive. Land use plans can guide when, where, and under what circumstances the Mining Law will be permitted to operate on specific tracts of federal land. Such restrictions will not rise to the level of outright withdrawals, defined in the Federal Land Policy and Management Act as "withholding" areas from entry. ${ }^{102}$ But they could be effective in discouraging Mining Law activity nevertheless. ${ }^{103}$ The legal path by which such restrictions can be imposed is set out elsewhere, and need not be repeated here. ${ }^{104}$

101. See supra text accompanying note 39 .

102. 43 U.S.C. § 1702(j) (1982).

103. In 1986, the BLM issued "supplemental program guidance" to its resource management planners that, among other things, required its plans to "identify," in those land areas open to operation of the Mining Law, "any terms, conditions, or other special considerations, if any, that may constrain mining activities. Such constraints may apply to major portions of the resource area, to specific areas within the resource area or to general types of operations conducted under the mining laws." BUREAU of Land Management Manual, Part 1624.3.31(A)2, added Nov. 14, 1986.

104. See THE MINING LAW, supra note 4, at 199-205. In late 1987 Congress adopted, as part of its giant budget reconciliation bill, a provision directing that BLM and National Forest lands continue 
Third, state and local governments may exert a stronger presence in regulating hardrock activities on federal lands, especially for environmental protection purposes. The United States Supreme Court has invited the states back into the picture with its recent decision in California Coastal Commission v. Granite Rock Co., ${ }^{105}$ and at least eight Western states already have regulatory control measures in place. ${ }^{106}$ The fallout from the Granite Rock decision is beginning to settle in the lower courts. The Wyoming Supreme Court, for example, has upheld the right of the state Environmental Quality Council to deny a federal mining claimant the right to mine. ${ }^{107}$ The claimant wanted to "procure boulders for home building and decorative stone" on a site of archaeological, historical and cultural interest in southern Wyoming that had been designated an area of critical environmental concern by the BLM. The state Supreme Court upheld the Council's finding that mining would result in substantial adverse impacts and ought to be denied. ${ }^{108}$

Fourth, Congress might be encouraged to make piecemeal reforms along the lines of recent efforts. The patent feature could be repealed outright, across the board, especially if the oil shale settlement legislation passes and proves to be a persuasive model. Congress has been willing to

to be managed under existing plans pending completion of new plans. It generally forbids challenges to those existing plans "on the sole basis" that the plan is outdated, but did not forbid challenges to "any and all particular activities. . .carried out under existing plans." See Pub. L. No. 100-202, \$314, 101 Stat. 1329-254 (1987).

105. 107 S. Ct. 1419 (1987).

106. See General Accounting Office, Federal Land Management: An Assessment of Hardrock Mining Damage, GAO-RCED-88-123BR at 17 (April 1988). This report also notes that most of the eight states have executed agreements with the Forest Service and the BLM dividing responsibility for regulating various aspects of reclamation. Id. at 18. See also Oversight Hearing, supra note 24, at 366$67,375-77$. For further commentary on the relation between state and federal law in this area, see Leshy, "Granite Rock" and the States' Influence over Federal Land Use, 18 EnvTL. L. 99 (1987); Freyfogle, Granite Rock; Institutional Competence and the State Role in Federal Land Planning, 59 U. Colo. L. REV. 475 (1988). The U.S. Forest Service has recently drafted regulations, not yet published for comment, that would attempt to preempt state reclamation regulation on national forests. U.S. Dep't of Agriculture, Forest Service, Proposed Amendments to 36 C.F.R. Part 228, Subpart A at 10 (draft copy on file with The Public Land Law Review). The Western Governor's Association (WGA) and the Conference of Western Attorneys General (CWAG) have gone on record in opposing this proposal. WGA Resolution No. 85-012 (July 12, 1988); CWAG Resolution No. 88-1 (July 29, 1988). In other respects, the proposed regulations would significantly tighten environmental controls, such as by strengthening the requirements for advance approval of plans of operations, tightening bonding requirements, and facilitating enforcement against those who use the Mining Law for non-mineral purposes.

107. LeFaivre v. Environmental Quality Council, 735 P.2d 428 (Wyo. 1987). On another front, Pitkin County, Colorado, has reportedly sued to require mining claimants in the nearby Maroon Bells Wilderness to obtain a county permit before commencing operations already approved by the Forest Service. SierRa 69-70 (March-April 1988). 430.

108. LeFaivre, 735 P.2d at 434-35. The BLM had not approved the claimant's operation. Id. at 
limit the patent feature of the law in several special categories. Patents can now be obtained only to the subsurface in wilderness areas and in some federal lands set aside primarily for military use. ${ }^{108}$ No patent at all is available in certain recreation and other special management areas. ${ }^{110}$

On the other hand, Congress has displayed a certain skittishness about tinkering with Mining Law reforms in particular contexts like military withdrawals, for fear of opening up the general subject. In October 1987, for example, the House passed a bill to withdraw federal lands used by two naval installations in California, but did not follow its 1986 precedent $^{111}$ of allowing the lands to be opened to a modified version of the Mining Law (no surface patent and "uncommon" varieties not included), because competing factions of the mining industry took differing positions. ${ }^{112}$ Specifically, industry moderates proposed a package of modest reforms to the Mining Law, applicable only to the withdrawn areas but widely perceived as a possible model for general reform. ${ }^{113}$ The American Mining Congress, on the other hand, opposed the package, insisting on no change in the Mining Law. In the face of this division in industry ranks, the House opted to keep the lands completely closed to the Mining Law. The episode suggests that intransigence can cost the industry access to federal land.

On environmental regulation, Congress has already cracked down a little on the BLM's relatively lax approach to requiring bonds sufficient to guarantee reclamation of mined sites. In the continuing appropriations act for the 1987 fiscal year, Congress modified the BLM's environmental regulations for Mining Law operations to require operators "with a history of noncompliance" with those regulations to post reclamation bonds in an

109. See 16 U.S.C. $\$ 1133$ (d)(3) (1982) (wilderness areas); Pub. L. No. 99-606, § 12, 100 Stat. 3467 (1986) (providing that if certain federal lands withdrawn for military use are opened to the operation of the Mining Law, any patent issued "shall convey title to locatable minerals only, together with the right to use so much of the surface as may be necessary for purposes incident to mining under the guidelines for such use established by the Secretary of the Interior by regulation").

110. See, e.g., 16 U.S.C. \& 460aa-9 (1982) (Sawtooth National Recreation Area). This restriction was upheld against constitutional challenge in Freese v. United States, 639 F.2d 754 (Ct. Cl.), cert. denied, 454 U.S. 827 (1981). For another proposal for piecemeal reform, see S. 2227, 134 CONG. REC. S3290 (daily ed. Mar. 29, 1988). This bill, introduced by Senator Bumpers, would authorize competitive leasing of quartz deposits on all lands in the Ouachita National Forest in Arkansas. The proposal was prompted by a recent "rush" on quartz mining, coupled with the fact that part of the Forest is subject to the Mining Law, and part is acquired lands subject to leasing under the Mineral Leasing Act for Acquired Lands. See 30 U.S.C. \$§ $351-59$ (1982).

111. See supra note 109.

112. See 133 Cong. Rec. H8097-8100 (daily ed. October 5, 1987); 12 Public LaNds News 7 (August 6, 1987).

113. The package included enlarging the claim size to 40 acres, abolishing the distinction between lode and placer claims, and eliminating extralateral rights. See 12 Public LaNds News 5-6 (October 15, 1987). 
amount sufficient to cover the cost of reclamation. ${ }^{114}$ Although seemingly modest, this statute had a couple of other potentially significant effects. First, it confirmed BLM's authority to issue and enforce the regulations, thereby dispelling any remaining doubt on that score. Second, it confirms the result in Granite Rock, recognizing state authority to regulate hardrock mining on federal lands, because Congress provided that "evidence of an equivalent bond posted with a State agency shall be accepted in lieu of a separate bond."115

Several recent General Accounting Office reports fertilized the seeds of reclamation. ${ }^{116}$ A GAO study published in August 1987 lauded the Forest Service's relatively aggressive policy to ensure that mine operators reclaim the lands disturbed. ${ }^{117}$ It also found that neither the agency officials nor the mining associations contacted could cite a single instance where mine operators "decided not to mine because of the cost of obtaining a financial guarantee."118 The March 1986 and October 1987 reports, on the other hand, scored the BLM for failing to carry out its responsibilities under the Federal Land Policy and Management Act by allowing mine sites to go unreclaimed. The latter study reported 20 of 30 mine sites examined on BLM lands remained unreclaimed. ${ }^{119}$ The most recent GAO report estimated that more than 424,000 acres of federal land disturbed by hardrock mining operations are unreclaimed, and only about one-third of these are subject to active authorized mining operations. ${ }^{120}$ The cost of reclaiming these lands was estimated at 284 million dollars. ${ }^{121}$ Other GAO

114. Pub. L. No. 99-500, § 101(h), 100 Stat. 1783-243 (1986). For other operators, bonding remains "at the discretion" of the BLM, which is essentially what the BLM regulations previously provided. 43 C.F.R. § 3809.1-9(b) (1987).

115. Pub. L. No. 99-500, 100 Stat. 1783-243 (1986).

116. See Federal Land Management: An Assessment of Hardrock Mining Damage, GAO/ RCED-88-123BR (April 1988); Federal Land Management: Limited Action Taken to Reclaim Hardrock Mine Sites, GAO-RCED-88-21 (October 1987); Federal Land Management: Financial Guarantees Encourage Reclamation of National Forest System Lands, GAO-RCED-87-157 (August 1987); Public Lands: Interior Should Ensure Against Abuses from Hardrock Mining, GAORCED-86-48 (March 1986).

117. Federal Land Management: Financial Guarantees Encourage Reclamation of National Forest System Lands, supra note 116, at 3.

118. Id. at 6.

119. Federal Land Management: Limited Action Taken to Reclaim Hardrock Mine Sites, supra note 116, at 1 . The Department of the Interior has disputed GAO's conclusion, arguing that only nine of the thirty sites in question were unreclaimed. One of GAO's errors, according the Interior, was not taking into account "the natural revegetation of disturbed land." See 13 PuBLIC LANDS NEWs 2-3 (March 17, 1988).

120. Federal Land Management: An Assessment of Hardrock Mining Damage, supra note 116, at 6.

121. Id. at 9. Reclamation can be more complicated for hardrocks than for conventional fossil fuels because of the large open pits often required for major hardrock extraction. See THE MiniNG LAW, supra note 4 , at 307,480 n.68. 
investigations are continuing, with reports expected in early $1989 .^{\mathbf{1 2 2}}$

Recent concerns about potential governmental liability under hazardous waste disposal laws ${ }^{\mathbf{1 2 3}}$ with respect to abandoned hardrock mining sites on unpatented mining claims could spur efforts to tighten environmental controls over existing operations to head off recurrences in the future. In the meantime, the courts are now being asked to hold mining companies liable for natural resource damage from old mining operations, ${ }^{124}$ and continue to uphold agency regulatory enforcement measures. ${ }^{125}$ The courts are also narrowing EPA's discretion to deal with mining wastes under various regulatory laws. ${ }^{126}$

Fifth, the BLM could rewrite its regulations on the Mining Law in a number of areas. In fact, BLM possesses potentially large, if largely unexplored, authority to fashion reforms without the need to go to Congress. It could, for example, make the assessment work requirement more meaningful by simple regulatory amendment. The Law has provided ever since 1872 that assessment work shall amount to "not less than $\$ 100$ " worth of work in any one year. ${ }^{127}$ There seems little doubt that the figure could be raised by a simple regulatory change. ${ }^{128}$ Furthermore, the BLM could tinker with the discovery requirement by regulation, something it has always been loathe to do. It has instead chosen to leave the subject to the

122. Conversation with Jim Zoia, Subcommittee on Mining and Natural Resources, House Committee on Interior and Insular Affairs (June 7, 1988).

123. See, e.g., Resource Conservation and Recovery Act, 42 U.S.C. $\$ 6961$ (1982); see also Stever, Perspectives on the Problem of Federal Facility Liability for Environmental Contamination, 17 Envtl. Law Rptr. (Envtl. L. Inst.) 10114 (April 1987).

124. See Idaho v. Hanna Mining Co., _ F.Supp. 27 Env't Rep. Cas. (BNA) 1868 (D. Idaho 1987) (mining company may be held liable under the federal Comprehensive Environmental Response Compensation and Liability Act for cleanup costs for mining wastes dumped by prior owners of the property). The U.S. Geological Survey recently reported that a plume of acidic groundwater measuring 2000 feet wide by ten miles long, and containing large concentrations of dissolved solids and metals related to mining and milling processes, is moving through the shallow aquifer system of the Globe-Miami area of Arizona. U.S. Dept. of the Interior News Release (March 11, 1987). For a list of forty-seven mineral-related "superfund" sites, about half of which appear to be outgrowths of Mining Law activities, see U.S. DePt. OF The Interior, The Mining Position of the United STATES-1987, 36-37 (Annual Report under the Mining and Minerals Policy Act). Cf. McCarthy, Reclaiming Butte, 49 MONT. L. REV. 267 (1988) (arguing for use of the law of subjacent support to require the Anaconda Company to financially support the rehabilitation of Central Butte).

125. See, e.g., United States v. Doremus, 658 F.Supp. 752 (D. Idaho 1987). See also supra note 61.

126. Environmental Defense Fund v. E.P.A, F.2d Nos. $86-1528,86-1584,27$ Env't Rep. Cas. (BNA) 1089, 1102 (D.C. Cir., July 29, 1988) (criticizing EPA's regulatory approach to hazardous mining wastes under the Resource Conservation and Recovery Act, but upholding EPA's decision to regulate other forms of mining debris as solid waste under the Act).

127. 30 U.S.C. $\S 28$ (1982).

128. This might, however, pose a dilemma for environmental groups, if raising the figure requires holders of inactive claims actually to undertake some disturbance of the landscape. From an environmental standpoint, sleeping dogs might better be left to lie. 
Department's Board of Land Appeals, which has produced a seemingly unending string of confusing decisions as to what the standard of discovery really is. ${ }^{129}$ The BLM could also reform mining claim contest procedures by clarifying, for example, who has the burden of going forward at different stages or in different kinds of contests, and with what kind of evidence. ${ }^{130}$ It could use its regulatory powers to reduce some of the complexities of disputes among rival claimants involving overstaking of claims, claim relocation and amendments, performance of assessment work and the like. It could also require more proof of possessory title to unpatented claims before plans of operations are reviewed, to ensure that only legitimate claims become subject to mineral activity. Finally, it could possibly require claimants to provide detailed results of exploration or assessment work, which would be made public and thus, over the long term, make exploration much more efficient, avoiding the need for each subsequent claim holder in the same area to start from the beginning. ${ }^{131}$

The Reagan Administration made noises about achieving some improvement by regulation, going so far as to create a working group to propose reforms, but the effort has apparently died without producing a public result. ${ }^{132}$ The Bureau of Land Management has, however, recently proposed to increase its fees for recording claims and processing patent applications substantially, and to impose new fees on such administrative matters as processing annual assessment work filings. ${ }^{133}$ The BLM estimates that the proposal would increase BLM's revenues from Mining Law administration about ten-fold, from $\$ 742,000$ to $\$ 6.4$ million a year. ${ }^{134}$ Industry has not expressed opposition. ${ }^{135}$ The Forest Service has recently sponsored rulemaking to deal with a chronic, low-visibility problem in administering the Mining Law. In April, 1988, it proposed specific regulatory definitions of so-called "common and uncommon varieties" of minerals, to try to sharpen the distinction between the two. ${ }^{138}$ Functionally, the difference determines whether the mineral in question is subject to location and patent under the Mining Law (if an "uncommon" variety) or subject to discretionary sale under the Surface Resources Act of

129. See The Mining LAw, supra note 4, at 119-67.

130. For some helpful suggestions along these lines, still almost entirely valid nearly fifteen years after they were suggested, see Strauss, Mining Claims on Public Lands, 1974 UTAH L. REv. 185. For a recent review of the effect of the FLPMA filing requirements on abuses of the Mining Law, see Jensen, Mining Claim Abuse: Has the FLPMA Filing Requirement Helped?, 1987 UTAH L. REv. 625.

131. See The Mining Law, supra note 4, at 51-54.

132. Id. at 162-63.

133. 53 Fed. Reg. 23720 (June 23, 1988).

134. U.S. Dep't of the Interior News Release (June 23, 1988).

135. 13 Public Lands News 3-4 (July 7, 1988).

136. 53 Fed. Reg. 15236-37 (1988). 
1955 (if not "uncommon"). ${ }^{187}$ This proposal illustrates that the agencies involved have substantial, unexercised rulemaking power to sharpen application of the Mining Law. ${ }^{138}$

In any event, the new administration taking office in January 1989 could have significant impact, not only by making $r$ gulatory changes, but also by withdrawals and by more aggressive enforcement of the environmental protection regulations and implementation of the land and resource planning processes. If that happens, the mining industry could become more interested in legislative reform.

Even the Reagan Administration has, in its waning years, balked at taking a more aggressive stance toward promoting mineral development. In late 1986, a draft "Mineral Resources Policy" was forwarded by BLM's Acting Assistant Director for Energy and Mineral Resources to the Director for adoption. ${ }^{199}$ It would have had BLM explicitly assume the role of "minerals advocate" in the federal establishment, to "maximiz[e] opportunities for land use by mineral developers" through "aggressive management" within limited constraints. ${ }^{140}$ Significantly, environmental protection was not expressly mentioned in the policy; under it, BLM would have committed itself only to identify the "least burdensome. . .reclamation practices possible."141

Environmental groups, led by the National Wildlife Federation, objected to its pro-mineral development tilt, arguing among other things that the proposal would "turn the Bureau into a tax-supported lobby for the minerals industry."112 Shortly thereafter, BLM Director Burford rejected the proposed policy. He issued a short statement that reaffirmed the

137. 30 U.S.C. $\$ 611$ (1982). Congress itself has recently hinted that it is running out of patience with the seemingly endless litigation seeking to determine what is an "uncommon" variety of these widely occurring minerals such as sand, stone, gravel, pumice, pumicite, cinder, and clay. In legislation giving the executive branch the power to open certain federal lands withdrawn for military purposes to the Mining Law, Congress specified that no varieties of these minerals, whether "uncommon" or not, would be subject to location under the Mining Law. Pub. L. No. 99-606, $\$ 12$ (c), 100 Stat. 3467 (1986).

138. Some possible kinds of regulatory changes can be gleaned from experience with other minerals. For example, in its proposed regulations to implement the Federal Onshore Oil and Gas Leasing Reform Act of 1987, see supra note 81 , the BLM has proposed to deny leases and lease assignments to entities who have defaulted on a reclamation bond within the previous five years, or on which a formal penalty for noncompliance with reclamation requirements has been imposed. See 53 Fed. Reg. 9214, 9222 (March 21, 1988) (proposed to be codified at 43 C.F.R. $\$ 3102.51-(f)$ ).

139. U.S. Dep't of the Interior, Bureau of Land Management, Instruction Memorandum No. 87-167 (Dec. 9, 1986) (transmitting draft Mineral Resources Policy Statement) (copy on file with THE Public Land Law ReviEw). It would have applied to all minerals under BLM's jurisdiction, not simply to the Mining Law.

140. Id. at $1-1$.

141. Id.

142. Letter from Jay D. Hair, Executive Vice-President, National Wildlife Federation, to Secretary of the Interior Donald P. Hodel (Jan. 16, 1987) (although it incorrectly states the date as 1986) (copy on file with The Public Land Law Review). 
general goal of multiple use in BLM management, and concluded that the "internal staff draft revision to our Mineral Resources Policy no longer merits consideration. . .."143

This episode illustrates that the mining industry lacks the clout, even within the councils of the most pro-minerals development administration within memory, to obtain a generally permissive mineral development policy. This failure suggests that, absent legislative reform of the Mining Law, the problems the Law poses for the industry will not abate, and the modern trend toward more stringent regulatory controls will probably continue, along the various lines sketched out above. ${ }^{144}$ Even continued trumpeting about the need to develop more domestic supplies of certain critical or strategic hardrock minerals appears not likely to move either Congress or the executive branch. ${ }^{145}$

Finally, environmental groups themselves cannot be expected to be quiescent in using litigation, long one of their favorite tools, to enforce the requirements of existing law. For example, a coalition of groups led by the Sierra Club has successfully sued both the Park Service and the BLM, using NEPA, FLPMA, and the Clean Water Act, to promote stronger regulation of hardrock placer miners in Alaska. ${ }^{146}$ The web of existing

143. Statement by the Director, U.S. Dep't of the Interior, Bureau of Land Management (Jan. 23, 1987) (copy on file with The Public Land Law Review).

144. For example, the now-scotched draft policy would have required BLM's "land use plans and management decisions" to "recognize" that, given "proper design and reclamation practices," mineral activity does not "significantly diminish long term productivity of the lands for other uses or preclude attainment of long term management objectives for surface values and resources." U.S. Dep't of the Interior, Bureau of Land Management, Instruction Memorandum No. 87-167, supra note 139, at 1-2. The Dircctor's rejection of the policy seems to signal that the BLM's planning processes will, instead, take a more balanced view of mineral activity. That means, in turn, increasing site-specific constraints on hardrock mineral development will probably emerge in BLM plans over the next several years.

145. See The Mining Law, supra note 4, at 342-46. The House of Representatives recently passed a bill requiring the Bureau of Mines to develop new mining and mineral processing technologies to reduce the United States' dependence on Russian and South African sources of important minerals and materials. 134 CoNG. REC. H6542 (daily ed. Aug. 8, 1988). Despite industry's efforts over the years to use the strategic minerals issue to leverage looser environmental controls and greater access to the federal lands, the House bill, carried by Congressman Rahall, does not deal with either. On another front, Secretary of the Interior Hodel recently emphasized that the Department's program to develop the minerals located under the oceans on the Outer Continental Shelf, which would be under a discretionary leasing system unlike the Mining Law, was designed "to reduce U.S. dependence on foreign sources of strategic and critical minerals." U.S. Dep't of the Interior News Release (Aug. 18, 1988).

146. See Sierra Club v. Penfold, 664 F. Supp. 1299, 1311 (D. Alaska 1987) (involving BLM's failure to comply with NEPA and the Alaska National Interest Lands Conservation Act, the court describing the agency's overall compliance record as "poor"); Northern Alaska Environmental Center v. Hodel, 803 F.2d 466 (9th Cir. 1986) (affirming the district court's injunction requiring the Park Service to prepare an environmental impact statement assessing the cumulative impacts of several mining operations on national park units, and halting mining until the EIS is prepared). For another type of judicial involvement not stemming directly from the Mining Law, see Bradbury v. Phillips 
requirements seems likely to continue to tighten and become even more tangled.

\section{CONCLUSION}

Major legislative reform of the Mining Law is still highly problematic. One can envision how it might occur, but a number of pieces have to fall into place before it can become a reality, and the teachings of history advise against holding one's breath waiting for it. But the Law has never been static; it has been steadily changed by a variety of mechanisms-piecemeal legislative reform, judicial interpretation, and administrative implementation. The future will not be different, even if the major players in and out of Congress find compromise beyond reach.

The Mining Law has assumed a mythic status, both venerated and vilified. A major item of unfinished legislative business, it offers one of the great challenges of natural resource lawmaking. It is good to have reform bruited about once again. For students of public land politics, the last decade or so has seemed curiously empty without it.

Petroleum Co., 815 F.2d 1356 (10th Cir. 1987) (upholding award of compensatory and exemplary damages to property owner after an altercation with mining claimants engaged in uranium exploration on federal mining claims. The surface where the defendants wanted to drill was privately owned, and the defendants had permission from the surface owner and from the BLM, but were on the wrong parcel of land as a result of a surveying error). 
HeinOnline -- 9 Pub. Land L. Rev. 301988 